\title{
Analisis Peran Kelembagaan Lokal Nelayan dan Strategi Pengembangannya dalam Pengelolaan dan Pemanfaatan Telur Ikan Terbang di Kabupaten Polman Sulawesi Barat
}

\author{
Analysis of Role and Development Strategy Local Fishermen Institutional in The \\ Management and Utilization Flying Fish Eggs at Polman District West Sulawesi \\ Djumran Yusuf ${ }^{1)}$, A. Adri Arief ${ }^{1)}$, Amiluddin ${ }^{1)}$, Syamsu Alam Ali ${ }^{2)}$, \\ M. Yusran Nur Indar ${ }^{2}$ \\ 1) Dosen Program Studi Sosial Ekonomi Perikanan, ${ }^{2)}$ Dosen Program Studi Manajemen \\ Sumberdaya Perikanan, Departemen Perikanan, Fakultas Ilmu Kelautan dan Perikanan \\ Universitas Hasanuddin, Makassar. e-mail: jumranyusuf@yahoo.co.id
}

\begin{abstract}
Abstrak
Tujuan penelitian ini adalah sebagai berikut : (1) Mengkaji keberadaan "lembaga" dalam masyarakat, baik dalam artian "wadah" maupun dalam artian "aturan dan norma" mengenai pemanfaatan sumberdaya ikan terbang. (2) Menganalisis profil dan peran lembaga masyarakat dalam kaitannya dengan pengelolaan sumberdaya perikanan. (3) Menelusuri faktor-faktor penjelas bagi ketidakberdayaan lembaga masyarakat dalam mengarahkan dan membentuk perilaku positif terhadap lingkungan sumberdaya perikanan. (4) Revitalisasi peran kelembagaan lokal yang aplikatif atau akomodatif dalam pengelolaan dan pemanfaatan sumberdaya telur ikan terbang. Metode yang digunakan adalah kualitatif (qualitative research) yang bersifat deskriptif kualitatif empirik dengan teknik efek snowball melalui pendekatan triangulasi, dan menggunakan metode grounded research. Data dikumpulkan melalui wawancara mendalam, pengamatan terlibat, dan penggunaan dokumen. Analisis data menggunakan pendekatan componetial analysis mulai dari reduksi, penyajian dan kesimpulan data. Hasil yang ditemukan bahwa perilaku nelayan tuing-tuing Desa Pambusuang masih dominan mempertahankan nilai tradisi sehingga eksploitasi ikan dan telur ikan terbang berlandaskan tingkat kebutuhan dan keberlanjutan ekosistem. Fungsi kelembagaan non formal telah terinternalisasi dalam pengelolaan dan pemanfaatan telur ikan terbang. Sementara kelembagaan formal menunjukkan peran dan fungsi yang belum optimal dalam mengintegrasikan diri ke dalam praktek-praktek tradisi yang mendukung upaya pelestarian ikan terbang. Skenario sistim kelembagaan dalam pengelolaan dan pemanfaatan ikan dan telur ikan terbang yang aplikatif, akomodatif harus merujuk kepada aksesibilitas yang terbuka bagi masyarakat (nelayan) dalam menyalurkan aspirasi dan partisipasinya yang terwadahi oleh pengitegrasian antara kelembagaan formal dan non formal berdasarkan konteks lokal.
\end{abstract}

Kata Kunci : Pengelolaan, Nelayan, Kelembagaan Lokal, Telur Ikan Terbang

\begin{abstract}
Objectives of research are as the followed: (1) Assess the existence of "institution" in society, both in the sense of "container" as well as in the sense of "rules and norms" that have an impact on the management of flying fish. (2) Analyze the profile and role of public institutions in connection with the management of fishery resources. (3) Browse the factors explained for the powerlessness of the public institutions in direct and shaping positive attitudes towards the environment fishery resources. (4) Revitalizing the role of local institutions applicative or accommodation in the management and used flying fish eggs. The methods used is descriptive qualitative empirical with snowball effect through triangulation approach, and used grounded research methods. Data were collected through interviews, participant observation, and use documents. Analysis of data used qualitative analysis approach ranges from data reduction, data presentation and conclusions. Results found that the behavior of Flying Fish fisher at Village Pambusuang still retain traditional values so that the exploitation of flying fish and eggs based on the level of demand and ecosystem sustainability. The function of non-formal institutions have been internalized in the management and utilization of flying fish eggs. While the formal institutional demonstrated the role and functions were not optimal in integrated into the traditional practices that support conservation of flying fish. Institutional system Scenario in the management and utilization of flying fish and eggs applicable and accommodating should refer to accessibility open to the people (fishermen) for delivering the aspirations and participation that were embodied by the integration between formal and non-formal institutions based on the local context.
\end{abstract}

Keyword : Utilization, Fisherman, Local Institutional, Flying Fish Eggs 
Djumran Yusuf : Analisis Peran Kelembagaan Lokal Nelayan dan Strategi Pengembangannya dalam Pengelolaan dan Pemanfaatan Telur Ikan Terbang di Kabupaten Polman Sulawesi Barat

\section{Pendahuluan}

Perkembangan peradaban dan pertumbuhan penduduk dunia menyebabkan pengelolaan sumberdaya perikanan semakin kompleks. Apabila dilihat dari konteks negara berkembang seperti Indonesia di mana faktor sosial, politik, ekonomi dan demografi yang tidak mendukung menyebabkan pengelolaan perikanan menjadi tantangan besar bagi siapapun yang terlibat didalamnya. Tidaklah mengherankan apabila kemudian selama enam puluh tahun lebih bangsa ini merdeka, sektor perikanan belum menunjukkan potensinya sebagai sektor yang dapat diunggulkan, meski realitas potensi fisik dan geografis sumberdaya perikanan jauh lebih baik daripada negara-negara di Asia lainnya. Dibalik peran strategis dan prospek potensi dari ekosistem pesisir dan lautan beserta sumberdaya alam yang terdapat di dalamnya, terdapat berbagai kendala dan kecenderungan yang mengancam kapasitas berkelanjutan (sustainable capacity). Berdasarkan kajian Balai Riset Kelautan dan Perikanan tahun 2005, mengilustrasikan bahwa tingkat pemanfaatan sumberdaya ikan umumnya sudah menunjukkan gejala lebih tangkap (overfishing) pada beberapa wilayah pengelolaan perikanan, yang ditandai dengan menurunnya trend produksi sumberdaya ikan dan perubahan komposisinya seperti menurunnya rata-rata panjang ikan yang tertangkap disamping makin mendominasinya ikan-ikan yang dahulu umumnya dikategorikan sebagai ikan tangkapan samping atau by catch.

Demikian pula dengan perilaku destruktif manusia (nelayan) atas sumberdaya perikanan, khususnya ikan terbang tampak semakin mencemaskan dalam beberapa tahun belakangan ini, produksi telur ikan tebang di Sulawesi Barat dari tahun ke tahun terus menunjukkan kecenderungan yang semakin menurun akibat kegiatan eksploitasi yang semakin intensif untuk melayani permintaan pasar baik domestik maupun ekspor yang semakin meningkat dengan harga pasaran yang cukup tinggi. Adanya kegiatan pengambilan induk dan telur ikan terbang secara terus menerus tanpa adanya aturan pengelolaan (regulasi) baik secara formal maupun non formal, maka dikhawatirkan populasi ikan terbang yang ada di Sulawesi Barat akan mengalami kepunahan.

Kaitan dari ilustrasi diatas dapat diringkas dari hasil penelitian yang dilakukan oleh peneliti sebelumnya bahwa pengelolaan sumberdaya perikanan secara umum, paling tidak ada empat persoalan pokok pengelolaan sumberdaya perikanan, yaitu :(1) persoalan Biofisik; terus berlanjutnya destructive fishing; bom dan bius (termasuk pengambilan telur ikan terbang secara masif); (2) persoalan ekonomi pada masyarakat pesisir, terbatasnya lapangan kerja, pengangguran, rendahnya produktivitas, fluktuasi harga ikan, dan rendahnya pendapatan serta kemiskinan; (3) persoalan sosial, rendahnya kesadaran dan pengetahuan tentang pentingnya konservasi dan pengelolaan sumberdaya perikanan, terbatasnya partisipasi masyarakat dalam pengelolaan sumberdaya perikanan, dan berkembangnya persepsi negatif terhadap hubungan dan interaksi manusia dengan sumberdaya alam; dan (4) persoalan kebijakan, belum jelasnya kebijakan pengelolaan sumberdaya perikanan secara riil, terbatasnya sosialisasi kebijakan, dan terbatasnya partisipasi masyarakat dalam pengembangan, formulasi dan implementasi kebijakan (Hutomo, 1985; Ali, 1993; Salman, 2003, Agusanty, 2004; Arief, 2007; Yusuf, 2013).

Jika dikaitkan dengan kelembagaan lokal sebagai pedoman bertingkah laku masyarakat, dapat disimpulkan bahwa setiap masyarakat memiliki rule of the game (kelembagaan) secara lokalitas di dalam mengatur kehidupannya termasuk mengelola sumberdaya alamnya. Misalnya pengelolaan sumberdaya perikanan seperti Sasi di Maluku (Nikijuluw, 1994; Huliselan, 1996; Kissya, 1996; Lakollo, 1996; Mantjoro, 1996; Novaczek et al., 2001), Awigawig di Bali dan Nusa Tenggara; Panglima Laut di Nangroe Aceh Darussalam (Nurasa et al., 1994; Nikijuluw, 1996), Kaombo Tayino Wabula di Buton (Tahara, 2002; Gaffar, 2012).

Pertanyaan yang hendak dijawab melalui penelitian ini adalah "Apa yang sedang terjadi dengan 'lembaga masyarakat', yang lingkungan alamnya (sumberdaya perikanan) terus terdegradasi?" Jika "lembaga" dipandang sebagai "norma/aturan" yang seharusnya menjadi "pedoman berperilaku" dari suatu komunitas atau juga sebagai "wadah" yang menghimpun kebersamaan dalam mendorong tindakan kolektif, pertanyaannya adalah "apakah sedang dan telah terjadi pengabaian atas kelembagaan-kelembagaan yang ada dalam masyarakat?" sehingga perilaku destruktif manusia atas lingkungannya terus berlangsung? Permasalahan-permasalahan ini menjadi dasar bagi perlunya pengkajian secara kritis hubungan antara "kelembagaan", 
masyarakat dengan "perilaku eksploitasi telur ikan terbang secara masif" Apakah pernah ada atau masih ada "kelembagaan" dalam masyarakat yang seharusnya dapat menjadi acuan berperilaku atau wadah kolektif dalam mengatur hubungan manusia dengan sumberdaya perikanan? Kalau pun ada, kenapa kelembagaan (sebagai norma/aturan dan wadah) tidak mampu mengarahkan perilaku masyarakat dalam mengelola dan memelihara kelestarian sumberdaya perikanan (ikan terbang, khususnya telur ikan terbang).

\section{Metode Penelitian}

Pendekatan kualitatif (model dominat-lest dominant design) (Creswell, 1994). Jenis penelitian deskriptif kualitatif empirik, dan menggunakan metode grounded research sehingga dalam pendekatannya lebih mementingkan kedalaman yang bersifat spesifik dan holistik dengan tujuan untuk memahami suatu konteks atau situasi. Pengamatan terlibat aktif terpraktekkan dengan berusaha memperlama keberadaan dalam komunitas, intensif observasi dan wawancara (in-depth). Desa Pambusuang Kecamatan Balanipa Kabupaten Polman (Sulawesi Barat) sebagai wilayah kasus dengan dasar pertimbangan metodologis berdasarkan survey awal yang dilakukan, yakni : (1) Di dua desa ini mayoritas penduduknya menggantungkan hidupnya dalam bidang perikanan (nelayan), khususnya sebagai nelayan yang menangkap dan mengumpulkan telur ikan terbang ; (2) Dalam perkembangannya, sebagian besar nelayan masih mempertahankan pengetahuan tradisional dalam kegiatan kenelayanan sebagai warisan dari leluhurnya serta eksistensi kelembagaan lokal dalam pengelolaan sumberdaya perikanan tangkap. Penelitian dilakukan pada Bulan Januari - April 2015.

Metode analisis utama yang digunakan adalah analisis data kualitatif, yaitu usaha analisis berdasarkan kata-kata yang disusun ke dalam bentuk teks yang diperluas (Miles dan Huberman, 1992). Tahapan analisis data di mulai dari reduksi data, penyajian data dan kesimpulan berdasarkan reduksi dan penyajian data.

\section{Hasil dan Pembahasan}

Perilaku Nelayan Torani dalam Aspek Sosial, Ekonomi serta Budaya yang Terkonstruksi Dalam Sistem Sosial Masyarakat

Analisis perilaku nelayan torani dalam aspek sosial, ekonomi serta budaya terhadap pengelolaan dan pemanfaatan ikan terbang yang terkonstruksi dalam sistem sosial masyarakat di Desa Pambusuang. Sistem sosial masyarakat disini dimaksudkan sebagai gejala sosial yang pendekatannya ditekankan pada tiga (3) aspek, yaitu; hubungan masyarakat dengan sang pencipta; hubungan antara masyarakat itu sendiri; dan hubungan masyarakat dengan sumberdayanya. Ketiganya inilah yang diasumsikan mewarnai perjalanan pemanfaatan dan pengelolaan sumberdaya di wilayah pesisir dan lautan pada ruang sosial masyarakat yang terus berdinamika, (Tabel 1).

Tabel 1. Konstruksi Hubungan Masyarakat dalam Pemanfaatan Telur Ikan Terbang

Table 1. Construction of Public Relations in the Utilization of Flying Fish Eggs

\begin{tabular}{|c|c|c|}
\hline & Temuan & Keterangan \\
\hline \multirow[t]{3}{*}{$\begin{array}{l}\text { Hubuangan } \\
\text { Masyarakat Nelayan } \\
\text { dengan Sang Pencipta }\end{array}$} & $\begin{array}{l}\text { Pencampuran antara kepercayaan } \\
\text { lama yang bersifat imanensi } \\
\text { dengan kepercayaan dari agama- } \\
\text { agama profetis, khususnya islam } \\
\text { yang bersifat transedensi }\end{array}$ & $\begin{array}{l}\text { Dijumpai pada praktek-praktek } \\
\text { ritual baik dalam aktivitas budaya, } \\
\text { maupun praktek keagaaman. }\end{array}$ \\
\hline & $\begin{array}{l}\text { Masih ditemukan pemitos- } \\
\text { sakralan terhadap unsur-unsur } \\
\text { alam melalui serangkaian upacara } \\
\text { tradisi }\end{array}$ & $\begin{array}{l}\text { Semua alat produksi yang dibeli } \\
\text { harus diselamati dan tempat-tempat } \\
\text { yg dianggap keramat dilakukan } \\
\text { ritual }\end{array}$ \\
\hline & $\begin{array}{l}\text { Kepercayaan yang bersifat mitos, } \\
\text { ritus, fetis, magis masih menjadi } \\
\text { adat kenelayanan }\end{array}$ & $\begin{array}{l}\text { Diwujudkan sebagai simbol } \\
\text { komunikasi dengan alam metafisik }\end{array}$ \\
\hline $\begin{array}{l}\text { Hubungan antara } \\
\text { masyarakat }\end{array}$ & $\begin{array}{l}\text { Masih kental sistem kekerabatan } \\
\text { baik yang sifatnya bilateral } \\
\text { maupu parental }\end{array}$ & $\begin{array}{l}\text { Dijumpai dalam menyambung } \\
\text { siklus hidup dan rekrutmen tenaga } \\
\text { keria dalam kelompok usaha }\end{array}$ \\
\hline
\end{tabular}


Djumran Yusuf : Analisis Peran Kelembagaan Lokal Nelayan dan Strategi Pengembangannya dalam Pengelolaan dan Pemanfaatan Telur Ikan Terbang di Kabupaten Polman Sulawesi Barat

\begin{tabular}{|c|c|c|}
\hline Aspek Hubungan & Temuan & Keterangan \\
\hline \multirow{3}{*}{$\begin{array}{l}\text { Hubungan masyarakat } \\
\text { dengan sumberdaya }\end{array}$} & $\begin{array}{lrr}\text { Eksistensi } & \text { modal } & \text { sosial masih } \\
\text { menjadi } & \text { pola } & \text { hubungan } \\
\text { masyarakat } & & \end{array}$ & $\begin{array}{l}\text { produksi } \\
\text { Partisipasi warga } \\
\text { tergambarkan dengan baik dalam } \\
\text { kegiatan sosial, budaya dan } \\
\text { keagamaan }\end{array}$ \\
\hline & $\begin{array}{l}\text { Menjadi sebuah tradisi yang } \\
\text { dilestarikan }\end{array}$ & $\begin{array}{l}\text { Ada kebanggan sosial sebagai } \\
\text { nelayan pa'tuing-tuing (pewaris } \\
\text { tradisi) }\end{array}$ \\
\hline & $\begin{array}{l}\text { Masih meyakini kepercayaan } \\
\text { lama mengenai ikan terbang }\end{array}$ & $\begin{array}{l}\text { Berapa pemitos-sakralan terhadap } \\
\text { ikan terbang yang dijadikan } \\
\text { pedoman dalam aktivitas produksi }\end{array}$ \\
\hline
\end{tabular}

Sumber : Hasil olahan data primer, 2015.

\section{Peran Kelembagaan Lokal dalam Pengelolaan Sumberdaya Perikanan}

Penjelmaan prasyarat fungsi integrasi pada kelembagaan masyarakat nelayan di daerah ini umumnya berlangsung melalui relasi-relasi sosial budaya dalam bentuk kegiatan-kegiatan upacara adat kenelayanan, upacara linkaran hidup (life cycle), kegiatan-kegiatan perlombaan pada acara hari kemerdekaan (17 Agustus), dan ritual keagamaan (Maulid Nabi Muhammad S.A.W). Kegiatan upacara-upacara tersebut yang mereka lakukan, selalu diharapkan dapat memberi kontribusi keseimbangan yang dinamis dalam komunitas nelayan di desa ini. Ada kecenderungan bahwa keteraturan sosial dalam pelaksanaan kegiatan-kegiatan tersebut terwujud melalui adanya kekuatan regulasi sistem nilai dan norma, serta pranata-pranata sosial budaya yang terkait dengan kebutuhan sosial dan upacara tradisonal. Ada kecenderungan bahwa komunitas nelayan di daerah ini menjadikan upacara adat kenelayanan dan upacara lingkaran hidup, serta ritual keagamaan sebagai sebuah media integrasi diantara mereka. Penjelmaan keteraturan dalam upacara tradisi kenelayanan dan lingkar kehidupan, serta ritual keagamaan berlangsung melalui proses regulasi sistem nilai dan norma kepercayaan serta pranata-pranata sosial budaya yang terkait dengan kebutuhan upacara, dengan itu internalisasi nilai-nilai pemenfaatan dan perlindungan terhadap sumberdaya perikanan termanfestasi didalamnya.

Setiap individu harus mempunyai kepercayaan bahwa solidaritas sebagai landasan untuk dapat menumbuhkan solidaritas dan kepercayaan kepada masyarakat yang lebih luas. Oleh karena itu, praktek-praktek solidaritas dan integrasi ditumbuhkembangkan untuk mencegah terjadinya individualisme dalam masyarakat. Konteks ini terlihat jelas pada kelompok konservatif yang memiliki norma bersama terhadap peraturan perilaku (behavior). Keputusan yang harus diambil mengarah pada kepentingan bersama dengan tidak menghilangkan hak asasi manusia sebagai makhluk sosial dengan melakukan berbagai penyesuaian (Suandi 2007). Konteks ritual dalam perspektif dalam kelembagaan lokal masyarakat (di daerah kasus), berbagai ritual yang melibatkan partisipasi warga, baik pada masa pra-produksi, produksi maupun distribusi, memiliki makna tersendiri di dalam ranah spiritualitasnya. Pelaksanaan ritual-ritual tersebut tidak sekedar bagian dari "kewajiban" yang harus dilakukan, tetapi sekaligus "transaksi spiritual "antara manusia dengan Tuhan. Oleh karena itu, motivasi ritual nelayan sarat dengan makna peneguhan hati dan keselamatan. Ritual terinterpertasikan sebagai " transaksi" kepada Tuhan agar diberi keselamatan dalam menjalankan aktivitas di laut yang menyimpan kekuatan supranatural yang sewaktu-waktu menebar ancaman.

Prosesi-prosesi ritual terus berlanjut di masyarakat setelah beberapa hari berada di laut dan mendapatkan hasil yang menggembirakan. Disamping karena mendapatkan hasil juga akan bertemu dengan keluarga yang sudah lama ditinggalkan begitu pula keluargan yang ditinggal selama beberapa hari juga akan merasa senang dan menyambut suami-suami mereka dengan baik karena akan berkumpul lagi dalam satu keluarga.

Ketika semuanya sudah rampung, dan hasil produksi atau tangkapan telur ikan terbang selesai dipasarkan para nelayan dapat mengambil pembagian uangnya di ponggawa posasi. Hasil produksi yang diperoleh setiap 
nelayan jumlahnya tidak tetap dalam setiap musim tergantung banyak sedikitnya hasil yang diperoleh. Apabila hasilnya lumayan bagus, maka ponggawa darat biasanya menggelar ritual mabaca-baca; sejenis upacara syukuran. Pelaksaa ritual mabaca juga menyangkut beberapa dimensi yaitu; pertama, waktu pelaksanaan. Ritual mabaca-baca biasanya dilakukan setiap nelayan kembali dari pelaksanakan aktivitas penangkapan ikan terbang dan telur ikan terbang. Waktu pelaksaannya secara umum menyesuaikan kegiatan para nelayan itu sendiri, dan kebanyakan memilihi malam sesudah magrib.

Kedua, pelaku ritual. Orang-orang terlibat dalam pelaksanaan ritual mabaca-baca, terdiri dari guru baca, undangan dan tuang rumah sendiri. Guru baca selalu dipercayakan memimpin jalanya ritual dan yang lainnya sebatas sebagai peserta ritual. Ketiga, bahan, simbol dan maknanya. Pelaksanaan ritual mabaca tidak terlalu banyak hidangan khusus yang disiapkan. Ritual ini sekedar membaca doa sebagai tanda syukur karena mereka sudah kembali dengan selamat dan membawa hasil yang lumayan. Keempat, pelaksanan ritual. Prosesi ritual ini dilakukan di rumah ponggawa dengan mengadakan makan bersama dan doa syukur yang dipimpin oleh seorang ustaz atau guru agama yang dipercaya.

Skenario Peranan Kelembagaan yang Aplikatif atau Akomodatif dalam Pengelolaan dan Pemanfaatan Ikan Terbang dan Telur Ikan Terbang

Kongritiasasi kreasi peranan dan fungsi kelembagaan dalam pengelolaan dan pemanfaatan ikan terbang dan telur ikan terbang sumberdaya pesisir yang aplikatif dan komunikatif pada masyarakat pesisir, maka dapat diinternalisasikan dalam skenario sistem pengelolaan sumberdaya pesisir sebagai berikut :

Skenario 1: Optimalisasi Peran Instruktif Pemerintah dalam Pembentukan Kelembagaan Berbasis Masyarakat dalam Pengelolaan Sumberdaya Pesisir

Pembentukan dan pengelolaan sumberdaya pesisir tidak harus terlepas dari peran pemerintah. Peran pemerintah dalam pembentukan dan pengelolaan sumberdaya pesisir harus meliputi sosialisasi tentang pengelolaan seperti penutupan sementara wilayah restoking benih ikan terbang, pemberian bantuan pemberdayaan masyarakat dalam menciptakan mata pencaharian alternative sebagai pengalihan pendapatan ketika terjadi closed sesson termasuk diantaranya pemberian bantuan rumpon (rumah ikan), penyelenggaraan pelatihan pengawasan dan studi banding. Pendanaan dan pendampingan pengelolaan sumberdaya pesisir oleh pemerintah tersebut berkecenderungan harus melibatkan kolaborasi dari empat komponen dasar, yaitu; pemerintah, masyarakat, swasta termasuk LSM serta pihak Perguruan Tinggi, termasuk dalam faktor project, dimana peran yang dilakukan tersebut untuk memenuhi target project yang dijalankan terkait implementasi atau aktifitas project.

\section{Skenario 2: Partisipatoris Masyarakat dalam Manajemen Konsultatif terhadap Pengelolaan Sumberdaya Pesisir}

Merupakan suatu program pengelolaan sumberdaya pesisir secara partisipatif yang bertujuan meningkatkan keikutsertaan seluruh nelayan di sepanjang pesisir pantai. Proses itu melalui pembentukan suatu komite untuk mewakili kepentingan dan menyuarakan keinginan masyarakat nelayan. Pendekatan manajemen konsultatif berkaitan dengan penentuan aturan-aturan dalam pengelolaan sumberdaya. Arah dari skenario ini, konteksnya kepada penguatan partisipasi masyarakat yang merupakan salah satu kunci keberhasilan dalam sistem pengelolaan berbasis masyarakat yang terwadahi oleh kelembagaan lokalnya. Rasa memiliki masyarakat yang kuat terhadap mekanisme pengelolaan dan partisipasi masyarakat dalam tahap-tahap perencanaan/pembentukan dan pelaksanaan/pengelolaan merupakan hal yang penting dalam mendukung keberhasilan pengelolaan sumberdaya pesisir berbasis masyarakat.

\section{Skenario 3: Peningkatan Kapasitas Masyarakat (Capacity Building) Masyarakat dalam Pengelolaan Sumberdaya Pesisir}

Memberikan pengutan terhadap partisipasi masyarakat dalam pengelolaan, dimaksudkan adanya ruang kesempatan masyarakat untuk mengelola sumberdaya mereka. Keterlibatan masyarakat dalam pengelolaan akan menentukan keberlanjutan pengelolaan sumberdaya pesisir kedepan. Tingkat partisipasi masyarakat tersebut sangat dipengaruhi oleh manfaat yang dirasakan 
Djumran Yusuf : Analisis Peran Kelembagaan Lokal Nelayan dan Strategi Pengembangannya dalam Pengelolaan dan Pemanfaatan Telur Ikan Terbang di Kabupaten Polman Sulawesi Barat

masyarakat. Rendahnya partisipasi masyarakat akan berdampak terhadap sistem pengelolaan tidak berlanjut setelah program berakhir. Karenanya diperlukan suatu upaya pemerintah untuk meningkatkan awareness (kesadaran) dan partisipasi masyarakat dalam pengelolaan sumberdaya pesisir, seperti penguatan kelembagaan, pengawasan, penegakan aturan, monitoring dan evaluasi sehingga masyarakat dapat melihat dan merasakan secara langsung dampak adanya sistem pengelolaan sumberdaya pesisir yang berbasis masyarakat.

Skenario 4 : Meningkatkan Kesadaran Masyarakat (Public Awareness) terhadap Potensi dan Kelestarian Sumberdaya Pesisir

Kesadaran masyarakat terhadap sumberdaya pesisir dan kelestariannya merupakan faktor penting dalam pengelolaan sumberdaya pesisir. Hal tersebut akan mempengaruhi perilaku masyarakat terhadap sumberdaya perikanan yang ada. Pengetahuan masyarakat terhadap aturan/larangan dapat memberikan pengaruh terhadap keberhasilan pengelolaan berbasis masyarakat sehingga masyarakat tidak melakukan hal yang dilarang dalam memanfaatkan sumberdaya perikanan (ikan terbang dan telur ikan terbang) sebagai sumber mata pencaharian.

\section{Skenario 5: Mengoptimalkan Manfaat Potensi Sumberdaya Pesisir Melalui Manajemen Kooperatif}

Kondisi ekologi yang baik di lokasi penangkapan mendorong dikembangkannya sumber-sumber ekonomi baru seperti ekowisata di lokasi tersebut yang diharapkan dapat memberikan dampak ekonomi terhadap masyarakat dan tidak menggantungkan pada hasil tangkapan ikan (telur ikan terbang), antara lain penyedia jasa akomodasi dan konsumsi serta guide bagi wisatawan. Hal-hal yang perlu diperhatikan adalah strategi pengembangan ekowisata tersebut tidak merusak atau menurunkan kualitas ekologi yang ada saat ini. Keberadaan Daerah Perlindungan Laut dapat pula dijadikan suatu wahana penelitian untuk melihat sejauh mana dampak DPL terhadap ekologi, ekonomi dan sosial masyarakat secara time series. Data tersebut dapat dimanfaatkan sebagai bahan rujukan evaluasi sistem pengelolaan yang berkelanjutan Disamping itu, manajemen kooperatif dimaksudkan agar pemerintah dan masyarakat relatif memiliki tanggung jawab dan peranan yang sama. Dengan sendirinya sitem pengelolaan sumberdaya berbasis masyarakat ini akan memperkuat kapasitas lembaga lokal.

\section{Skenario 6: Mengoptimalkan Manfaat Daerah Perlindungan Restocking terhadap Kondisi Ekologi dan Pendapatan}

Salah satu manfaat yang diharapkan antara lain dapat menjaga atau melindungi/ memperbaiki/ meningkatkan kualitas ekosistem terumbu karang. kelimpahan ikan di lokasi restocking mengalami peningkatan karena tidak adanya aktifitas penangkapan yang dilakukan di daerah tersebut. Selain itu, berpengaruh juga terhadap kelimpahan ikan. Suatu area yang dilindungi dapat meningkatkan settlement larva ikan sehingga dapat meningkatkan ketersediaan juvenile dalam populasi. Dampak perlindungan suatu kawasan perairan terhadap ikan antara lain kepadatan, biomassa dan nilai CPUE lebih besar daripada lokasi non-Daerah Perlindungan Restocking (DPR). Kondisi ekologi yang baik, diharapkan dapat meningkatkan pendapatan masyarakat. Peningkatan pendapatan masyarakat ini dapat diperoleh dari hasil penangkapan atau aktivitas lainnya seperti mata pencaharian alternatif dan ekowisata. Keberadaan perlindungan daerah restocking dapat meningkatkan pendapatan masyarakat melalui penangkapan maupun aktivitas lainnya. Pilot project mata pencaharian alternatif harus dikembangkan antara lain budidaya marine culture seperti; budidaya ikan terbang, budidaya rumput laut, budidaya kuda laut, teripang, lola dan abalone.

Skenario 7: Mengoptimalkan Manajemen Informatif dalam Pengelolaan Sumberdaya Pesisir sebagai Sumber Informasi Masyarakat

Melalui pendekatan ini, tanggung jawab untuk mengelola kuota setiap individu nelayan diserahkan oleh pemerintah kepada kelompok nelayan yang mengumpulkan dan mengelola seluruh kuota nelayan anggotanya. Kelompok nelayan bertanggung jawab untuk mengimplementasikan dan menjalankan regulasi, menetapkan sanksi, serta menata pertukaran kuota antar kelompok nelayan. Tanggung jawab pemerintah dalam hal ini adalah mengawasi kuota pada tingkat nasional 
yang dialokasikan serta tugas lain yang berkaitan dengan kebijakan perikanan nasional. Manajemen sumberdaya perikanan dengan cara ini bisa dikelompokkan sebagai bentuk kolaborasi manajemen informatif karena kelompok nelayan menginformasikan kepada pemerintah tentang regulasi yang diimplementasikannya.

\section{Skenario 8: Resolusi Konflik Melalui Pendekatan Manajemen Advokatif}

Pengelolaan sumberdaya pesisir dan lautan sangat erat hubungannya dengan masyarakat, interaksi masyarakat dengan lingkungan dan bagaimana memanfaatkan sumberdaya yang ada. Sebagian besar konflik dalam pengelolaan dan pemanfaatan sumberdaya timbul karena kesulitan dalam menjelaskan rezim kepemilikan. Jika tidak ada kesepakatan dalam bagaimana pengelolaan sumberdaya, konflik tidak dapat dihindari. Karenanya, penerimaan masyarakat terhadap program yang ada merupakan salah satu faktor penunjang keberhasilan pengelolaan DPR. Oleh karena itu bentuk pendampingan advokasi senantiasa harus menjadi bagian yang selalu terwadahkan dalam masyarakat.

\section{Skenario 9: Optimalisasi Pendanaan dalam Pengelolaan Sumberdaya Pesisir Berbasis Masyarakat}

Pendanaan adalah faktor penting dalam suatu pengelolaan. Pendanaan ini diperlukan dalam hal proses pembentukan sampai dengan pengelolaan. Dukungan pendanaan dan pengalokasian yang tepat dalam pengelolaan sumberdaya pesisir menjadi hal yang sangat urgen dalam keberhasilan dan pencapaian tujuan pengelolaan sumberdaya pesisir secara berkelanjutan.

Intisari yang dapat sarikan dalam penjelasan diatas adalah konteks pengelolaan sumberdaya pesisir (ikan terbang dan telur ikan terbang) yang aplikatif dan komunikatif pada masyarakat merupakan langkah strategis menggiring pendekatan sistem pengelolaan berbasis masyarakat dengan pendekatan yang altruistik. Artinya, sumberdaya yang ada sekarang tidak akan dimanfaatkan pada tingkat yang maksimun, melainkan pada tingkat yang optimun. Tingkat optimun akan menggiring pemanfaatan sumberdaya yang memberikan kepuasan kepada generasi sekarang tanpa mengurangi kepuasan atau kesempatan yang akan dinikmati oleh generasi berikutnya.

Kapasitas lembaga non formal dan formal yang terinternalisasi satu sama lain dalam satu bingkai pengelolaan sumberdaya pesisir (ikan terbang dan telur ikan terbang) akan menggiring kepada pemanfaatan yang bertanggung jawab, sehingga ikan terbang terutama telur ikan terbang tidak hanya direduksi untuk kepentingan ekonomi sesaat, melainkan sebagai sumberdaya potensial (ekologi, sosial dan budaya) yang harus berkelanjutan dan terwarisi bagi generasi yang akan datang.

\section{Kesimpulan}

1. Perilaku nelayan torani masyarakat di desa penelitian yang terkonstruksi oleh tatanan budaya masih terus mengalami kondisi transisional ke arah profit oriented yang hanya mengeskploitasi telur ikan terbang saja, meskipun nilai-nilai tradisi masih tetap dijumpai dalam dinamika aktivitasnya.

2. Fungsi kelembagaan non formal telah terinternalisasi dalam pengelolaan dan pemanfaatan telur ikan terbang, sementara kelembagaan formal menunjukkan peran dan fungsi yang belum optimal dalam mengintegrasikan diri ke dalam praktekpraktek tradisi yang mendukung upaya pelestarian ikan terbang.

3. Skenario sistim kelembagaan dalam pengelolaan dan pemanfaatan ikan terbang dan telur ikan terbang yang aplikatif dan akomodatif harus merujuk kepada aksesibilitas yang terbuka bagi masyarakat (nelayan) dalam menyalurkan aspirasi dan partisipasinya yang terwadahi oleh pengitegrasian antara kelembagaan formal dan non formal berdasarkan konteks lokal.

\section{Daftar Pustaka}

Agusanty, Harnita. 2004. Prakarsa dan Partisipasi Masyarakat Nelayan dalam Eksploitasi dan Konservasi Sumberdaya Hayati Perairan di Kabupaten Takalar (Studi Kasus Desa Tamasaju, Kec. Galesong Utara). (Tesis). PPS-UNHAS. Makassar.

Ali S. A dan Natsir Nessa, 1993. Penetasan Dan Perawatan Larva Ikan Terbang 
Djumran Yusuf : Analisis Peran Kelembagaan Lokal Nelayan dan Strategi Pengembangannya dalam Pengelolaan dan Pemanfaatan Telur Ikan Terbang di Kabupaten Polman Sulawesi Barat

Ditempat Pembenihan (Hatchery). Torani Bulletin Ilmu-Ilmu Pertanian Universitas Hasanuddin. Makassar

Amien, Mappadjantji (ed). 1995. Penyelenggara Negara dari Perspektif Kemandirian Lokal dalam Pokok-pokok Pikiran Amandemen UUD 1945 dari Perspektif Kemandirian Lokal. Universitas Hasanuddin. Makassar.

Arief, A. Adri. 2007. Artikulasi Modernisasi dan Dinamika Formasi Sosial Pada Nelayan Kepulauan di Sulawesi Selatan (Studi Kasus Nelayan Pulau Kambuno). (Disertasi) Program PascasarjanaUNHAS. Makassar.

Azwar Saifuddin, 1998. Sikap Manusia Teori dan Pengukurannya. Edisi II, Yogyakarta : Pustaka pelajar.

Basuki dan Nikijuluw. Victor P.H. 1996. KoManajemen dalam Perikanan Pantai Masyarakat Adat dan Pemerintah Indonesia, dalam BPPT-Wanhankamnas, Konvensi Benua Maritim Indonesia. Jakarta : BPPT-Wanhankamnas.

Bengen, D.G., 2005. Merajut Keterpaduaan Pengelolaan Sumber Daya Pesisir dan Laut Kawasan Timur Indonesia Bagi Pembangunan Kelautan Berkelanjutan. Disajikan pada Seminar Makassar Maritime Meeting, Makassar.

Boyd, H. Dan Charles, A., 2006. Creating Community-based Indicators to Monitor Sustainability of Local Fisheris. Ocean \& Coastal Management 49 (2006) 237 258.

Canada. www.elsevier.com/local/ocecoaman

Bungin, Burhan. 2003. Analisis Data Penelitian Kualitatif. Pemahaman Filosofis dan Metodologis ke arah Penguasan Model Aplikasi. PT. Raja Grafindo Persada. Jakarta.

Carter, J. A. 1996. Introductory Course on Integrated Coastal Zone Management (Training Manual). Pusat Penelitian Sumberdaya Manusia dan Lingkungan Universitas Indonesia, Jakarta.

Carter, R.W., 1988. Coastal Environment : An Introduction to the Physicsl, Ecological and Cultural System of Coastlines. Acad. Press Inc. San Diego, USA.

Creswell. J. W., 1994. Research Design Qualitative and Quantitative Approaches. London: SAGE Publications.
Dinas Perikanan dan Kelautan Sulsel. 2010. Laporan Tahunan Dinas Perikanan TK I Sulawesi Selatan. Makassar.

Koentjaraningrat, 1994. Metode Penelitian Masyarakat. Gramedia Pustaka Utama, Jakarta.

Mangunwijaya, Y.B. 1987. Teknologi dan Dampak Kebudayaan. Penerbit Yayasan Obor Indonesia. Jakarta.

Mattulada. 1997. Sketsa Pemikiran Tentang Kebudayaan, Kemanusiaan dan Lingkungan Hidup. Hasanuddin University Press. Ujung Pandang.

Mubiyarto. 1984. Nelayan dan Kemiskinan Studi Ekonomi dan Antropologi di Dua Desa Pantai. CV. Rajawali. Jakarta.

Nikijuluw, V.P.H., 2002. Rezim Pengelolaan Sumber Daya Perikanan. P3R, jakarta.

Nielsen dan Vedsmand, 1999. User Participation and Institutional Change in Fisheries Management: A viable alternative to the failures of 'top-down' driven control? Ocean and Coastal Management 42 (1999) $19-37$.

Salam, Muslim. 2005. Metodologi Penelitian Kualitatif : Menggugat Doktrin Kuantitatif. (Dokumen Materi Kuliah Metode Penelitian Kualitatif. Program Doktor Pertanian PPs Unhas, 2007). Makassar

Sallatang, Arifin, 1982. Pinggawa-Sawi: Suatu Studi Sosiologi Kelompok Kecil. Jakarta, Depdikbud.

Sallatang, Arifin. 2000. Strategi Pengembangan Masyarakat Pesisir. Universitas Hasanuddin. Makassar.

Salman, D. 2002. Pendekatan Partisipatoris dalam Perencanaan Pembangunan Daerah. Makalah Dipresentasikan dalam "Diklat Program Kepemimpinan Bappeda dalam Era Otonomi Daerah", Depdagri. Jakarta.

Salman. Darmawan. 2003. Pemberdayaan Masyarakat sebagai Kunci Keberhasilan $P P K$. Makalah disampaikan dalam "sosialisasi pembinaan dan pengendalian program pengembangan kecamatan (PPK) fase II dan pelatihan penguatan kinerja tim kordinasi PPK kebupaten dan pelaku PPK kecamatan" BPMP-SulSel. Makassar.

Skinner, 1976. The Experimental an Analysis of Behavior. New York Viking Press. 
Soedjito. 1987. Aspek Sosial Budaya dalam Pembangunan Pedesaan. Penerbit PT. Tiara Wacana. Yogyakarta.

Soekanto. Soerjono, 1996. Sosiologi Suatu Pengantar, Raja Grafindo Perkasa.

Sumaatmadja Nursid, 1998. Manusia Dalam Kontes Sosial Budaya dan Lingkungan . Bandung : CV. alfabet

Uphoff, Norman. 1986. Local Institutional Development: An Analytical Sourcebook With Cases. West Hartford, Conn, Kumarian Press

Widayati. 2003. Kajian Kelembagaan. Materi Semiloka. Studi/Kajian Perda Sektor
Kelautan dan Perikanan Propinsi Sulawesi Selatan. LP3MPK. Makassar.

Wirawan, Gandi. 2004. Perbedaan Orientasi Nilai dan Perilaku Prososial antara Suku Bangsa Melayu dan Suku Bangsa Tionghoa. (http://www.depsos.go.id / Balatbang / Puslitbang /2004).

Wulansari, Dewi. 2009. Sosiologi (Konsep dan Teori). Refika Aditama. Bandung.

Yusuf, Djumran. 2013. Studi Kelembagaan dalam Pengelolaan dan Pemanfaatan Telur Ikan Terbang (Kasus Desa Pallalakang Kabupaten Takalar dan Desa Pambusuang Kabupaten Polman). Desertasi. PPS. Unhas. Makassar. 